\title{
Prevalence of Gastrointestinal Tract Worms in Bali Cattle at Bali Cattle Breeding Center, Sobangan, Badung
}

\author{
Suratma NA, Dwinata IM, Oka IBM, Mubarok F, Alamsyah AN \\ Faculty of Veterinary Medicine, Udayana University \\ Jl. PB Sudirman, Denpasar, Bali, Indonesia \\ adisuratma@yahoo.co.id
}

\begin{abstract}
A study on prevalence of worms in gastrointestinal tract in Bali cattle in Sobangan Breeding Center Badung has been done. A total of 290 Bali cattle's faeces sample was evaluated using flotation concentration method and Parfitt and Bank methods. Results showed that the prevalence of worms in Bali cattle's gastrointestinal tract was 9.31\%. There were seven kinds of worms that infected, i.e. Paramphistomum spp, Fasciola spp, Bunostomum phlebotomum, Strongyloides papillosus, Trichostrongylus axei and Trichuris ovis. It is advisable to conduct periodically and continuously evaluation and treatment of parasitic infections in cattle. It also needs to be dessiminated good cattle management to the local community around Bali Cattle Breeding Center.
\end{abstract}

Key Words: Prevalence, Gastrointestinal Tract, Bali Cattle, Worm

\section{INTRODUCTION}

Sobangan Bali Cattle Breeding Center, Badung is owned by the Animal Husbandry, Fisheries and Marine Department Badung. In this breeding center, there are 290 of cattle breeders, in which their calves will be distributed to farmers in Badung Regency. Additionally, the breeding center is also planned to provide source of good calves in Bali. Therefore, the department with the Faculty of Veterinary Medicine Udayana University has a memorandum of understanding to implement Bali cattle health management in the breeding center. This cooperation aims are to provide healthy calves, and as a learning center or source of scientific experience for Faculty of Veterinary Medicine's students.

Aside from being a source of cattle that will be distributed to local areas in Bali, centers for breeding nursery is also a model for surrounding cattle ranchers and cattle breeders in Bali, in order to obtain a cow with good quality.

One of the infections that is routinely checked in Bali cattle at the breeding center is gastrointestinal worm infections (nematodes and/or trematodes). The evaluation is done as the case of worm infections in cattle can be affected by several factors, such as cattle raised management, the condition of the cattle region, the climate, etc (Taylor et al. 2007), therefore, the possibility of the infection in Bali cattle can occur at any time. In addition, worm infections in cattle can also affect the endurance of the cattle which may impact to other infectious diseases.

Thus, to obtain a healthy cattle, both the breeders and the calves, a study on worm infection in cattle worm is needed, so that the prevention and treatment of the infection can be performed accurately.

\section{MATERIAL AND METHODS}

\section{Research location}

Study was carried out at Sobangan Bali Cattle Breeding Center, which is located in Sobangan Village, Badung Regency. This farm belongs to an Sentra from the Badung 
Regency administration and managed by the Department of Animal Husbandry, Fisheries and Marine, Badung. This location is approximately $15 \mathrm{~km}$ from the City of Denpasar, in this area there are a few blocks cowshed maintained 290 cattles, elephant grass plants, animal feed processing sites, and veterinary clinic, cooperation with Faculty of Veterinary Medicine, Udayana University.

\section{Research sample}

Samples used and observed in this study were faeces derived from 290 cattles raised in this Farm Sentra.

\section{Research method}

An observational cross sectional study was used in this research. A total of 290 faeces of Bali cattle was evaluated by rectal exploration in each of the cattle sample. The observation of worms infection was evaluated in Parasitology Laboratory. Parfitt and Bank methods were used to evaluated trematod worm infection, while for nematode worm infection a flotation concentration method was used (Soulsby 1982; Zajac et al. 2012). The gathered data then were analyzed descriptively.

\section{RESULTS AND DISCUSSION}

After observation of 290 Bali cattle's faeces, its found that there were $27(9.31 \%)$ of the cattle infected with gastrointestinal tract worms. They were Paramphistomum spp, found in 7/290 (2.41\%) cattle; Fasciola spp, 9/290 (3.1\%), Bunostomum phlebotomum 6/290 (2.07\%); Strongyloides papillosus 7/290 (2.41\%), Trichostrongylus axei 10/290 (3.45\%), and Trichuris ovis 4/290 (1.38\%).

Although worm infection was found relatively prevalent, but it was categorized into a low severity infection. In addition, this infection needs to be concerned as the spread of the worm infection can be relatively fast, especially in the area where the risk factors can support the spread and development of the worms.

In comparison with the gastrointestinal worm infection in Bali cattle in other areas, there seems to be significantly difference. Fadli et al. (2014) reported that $21 \%$ of Bali cattle infected with nematode worms, whereas Putra et al. (2014) found that 27\% of Bali cattle infected with trematode worms. In addition, $52.78 \%$ of Bali cattle in Petang Village, Badung Regency (Yasa 2011). The different findings on worm infection in Bali cattle showed that cattle raised management, especially sanitation management practice in the Sobangan Breeding Center has been practically good. Sanitation management practice is an important factor that can minimize the infection of the gastrointestinal worms (Taylor et al. 2007; Zajac 2012). Besides, anti-worm treatment, as a part of good health management practice, needs to be periodically given to the cattle in order to prevent the spread of the worm infection.

Furthermore, management needs to do a more intensive, especially periodic and continuously evaluation of parasitic infections in cattle, so that parasitic infections can be reduced and controlled. As a result, the bovine growth can occur optimally. In addition, it should also be dessiminated cattle management at Bali Cattle Breeding Center, Sobangan, Badung to communities around the center, so it can provide cows with a good quality maintained around these centers. 


\section{CONCLUSION}

Based on the study results, it can be concluded that: (1) Prevalence of gastrointestinal tract in Bali cattle at Sobangan Bali Cattle Breeding Center is 9.31\%; (2) There are seven kinds of worms that infected the cattle, i.e. Paramphistomum spp, Fasciola spp, B. phlebotomum, S. papillosus, T. axei and T. ovis.

\section{REFERENCES}

Fadli M, Oka IBM, Suratma NA. 2014. Prevalensi nematoda gastrointestinal pada sapi Bali yang dipelihara peternak di Desa Sobangan, Mengwi, Badung. Indonesia Med Vet. 3:411-422.

Putra RD, Suratma NA, Oka IBM. 2014. Prevalensi trematoda pada sapi Bali yang dipelihara peternak di Desa Sobangan, Kecamatan Mengwi, Kabupaten Badung. Indonesia Med Vet. 3:394-402

Soulsby EJL. 1982. Helminth, arthropods and protozoa or domesticated animals. $7^{\text {th }}$ Ed. Philadelphia (US): Lea and Febiger.

Taylor MA, Coop RL, Wall RL. 2007. Veterinary parasitology. Oxford (UK): Blackwell Publishing.

Yasa IWS. 2011. Identifikasi cacing nematoda saluran pencernaan pada sapi Bali yang dipelihara di Petang, Kecamatan Petang, Badung. Denpasar (Indonesia): Fakultas Kedokteran Hewan, Universitas Udayana.

Zajac AM. 2012. Clinical veterinary parasitology. $8^{\text {th }}$ Ed. Iowa (US): Blackwell Publishing.

\section{DISCUSSION}

\section{Questions}

1. Why is this study important?

2. What is the next step after all know these results?

\section{Answers}

1. Because the observed cattles will be distributed to the public, so need to know the health status of the cattle.

2. It is recommended to the management of the breeding centers to conduct regular evaluation and follow-up if there are infected cattle. 